\title{
実在都市キャニオン内における実測值と風洞実験による流れ場の比較 実在都市キャニオン内の流れ場に関する風洞実験（その1） \\ COMPARISON BETWEEN WIND TUNNEL EXPERIMENTS AND \\ FIELD MEASUREMENT VALUES ON FLOW FIELD \\ IN REAL URBAN CANYONS
}

Wind tunnel experiments on flow field in real urban canyons (Part 1)

香月壮 亮*, 佐藤 歩**, 道岡武信**, 萩島 理***

\section{Takeaki KATSUKI, Ayumu SATO, Takenobu MICHIOKA and Aya HAGISHIMA}

\begin{abstract}
Improvement of outdoor ventilated environment contributes not only to energy-saving and suppression of $\mathrm{CO}_{2}$ but also to indoor air quality and its comfort. To consider outdoor well-ventilated environment, a flow field within ideal urban canyons has been investigated by wind tunnel experiment, but the behaviors of turbulence and mean characteristics of canyon vortices within real urban canyons are still not comprehended. In this study, a wind tunnel experiment for a real apartment complex was conducted to confirm the reproducibility of flow field within the canyon. The apartment complex is located at Musashino city, Tokyo, where field measurement was conducted. The buildings with a height more than two-stories were resolved within $200 \mathrm{~m}$ radius under the model length ratio of 1/150 was measured using both PIV (Particle Image Velocimetry) and LDV (Laser Doppler Velocimeter). These measurements at 5 points within the urban canyon were compared with field measurement values. The wind velocities and turbulent intensities obtained by both PIV and LDV fairly agreed with the field measurement values within the urban canyons, though a small-scale surface roughness like a balcony was not modeled in the present wind tunnel experiment.
\end{abstract}

\section{Keywords : Urban canyon, Flow field, Wind tunnel experiment, Laser Doppler Velocimeter, Particle Image Velocimetry \\ 都市キャニオン，流れ場，風洞実験，レーザ一流速計，粒子画像流速測定法}

\section{1. はじめに}

低炭素社会の実現に向けて，民生(業務その他および家庭)部門の エネルギー消費の増加を抑制するために，製造業ではトップランナ 一基準を採用しエネルギー消費効率を向上させている 1)。また，市 街地における省エネルギー対策では，「風の道」と呼ばれる市街地全 体の風通しが有効であり，ヒートアイランドに代表される市街地の 高温化を抑制し 2)，快適性を上げる効果がある。民生部門の主であ る建物に関しても，高断熱高気密，自然換気の導入，ヒートポンプ の利用などといった省エネルギーの対策が行われている。なかでも， 自然換気による屋内への効率的な風の導入方法に関する研究は数多 く行われており3，屋外の良好な風通しを確保することは，省エネ ルギーや $\mathrm{CO}_{2}$ 排出抑制に寄与寸るだけでなく, 屋内の空気環境やそ の快適性にも大きな影響を与える。

$*$ 電力中央研究所環境科学研究户

特別契約研究員・博士 (工学)

** 電力中央研究所環境科学研究所 主任研究員 $\cdot$ 博士 (工学

*** 九州大学大学院総合理工学研究院 准教授 $\cdot$ 博士 (工学)
これまでに, 街区を対象とした屋外の風通しに関して, 多くの風 洞実験による研究が行われてきた。例えば, 久保田ら 4)5 は実市街地 を対象とした風洞実験を実施し, 16 風向で地区全体の平均的な風通 しについて検討を行った。その結果，低層住宅地，中高層集合住宅 団地ともに地区のグロス建蔽率（道路等の公共用地を含めた全体面 積に対する建築面積の割合）の増大に伴って地区全体の風速の平均 值が低下すること，地区のグロス建蔽率が同じ場合には，中高層集 合住宅団地の方が地区全体の平均風速が大きくなり，建物群の高さ より中高層集合住宅団地の混在比率による平面形態の違いが重要で あることを明らかにした。義江ら ${ }^{6)}$ は香港の Mong-kok を対象に単 純化した建物モデル群を用いた風洞実験を行い，グロス建蔽率，グ ロス容積率（道路等の公共用地を含めた全体面積に対する建物の延 床面積の割合）および建物高さのバラツキ等が歩行者レベルの Visiting Researcher, Environmental Science Research Laboratory, Central Research Institute of Electric Power Industry, Dr. Eng.

Research Scientist, Environmental Science Research Laboratory, Central Research Institute of Electric Power Industry, Dr. Eng.

Assoc. Prof., Interdisciplinary Graduate School of Engineering Sciences, Kyusyu Univ., Dr. Eng. 
風速や気温分布に与える影響について検討した。その結果, 建物高 さのバラッキによって効果的に上空の冷気を街区へ取り入れること が可能であることを明らかにした。しかしながら, これらの研究に おける風通しの検討はキャニオン内の風向はあまり考慮せず風速に 焦点を当てている。屋外の良好な風通しを詳細に検討するためには, 風洞実験により都市キャニオン内の流れの挙動を把握することが重 要と考えられる。

単純化された都市キャニオンを対象に, 流れ場の詳細は様々な風 洞実験で検討されており, その一部の例を以下に示す。Brown et al. 7)は, 2 次元の都市キャニオンを対象に, 最も風下側の建物からおよ そ建物高さの 3.5 倍離れた下流近くに剥離の再付着点があることを 明らかにした。また Brown et al. ${ }^{81}$ は, 3 次元の都市キャニオンを対 象に実験を行い, 2 次元キャニオン内の循環渦の中心がキャニオン 中央付近に存在するのに対し, 3 次元のキャニオン内の循環渦の中 心はやや風上側へ移動することを明らかにした。 Leitl et al. ${ }^{9)}$ は, 都市のラフネスを模擬した 120 個のコンテナを並べた Mock Urban Setting Test(MUST) 10)を対象に, キャニオン群の中央で流れの鉛直 分布を計測し, 実測值の再現性の確認を行った。その結果, 風洞実 験では実測と大気安定度がやや異なるものの, 運動量フラックスは 良く一致することを明らかにした。Monnier et al. ${ }^{11)}$ は， $4 \times 3$ 列の ブロックに対してキャニオン内の 3 次元の流れを詳細に測定し, 主 流方向の街路幅と模型高さのアスペクト比の差異だけでなく, 流入 風のキャニオンに対する入射角が流れ場に与える影響を検討した。 主流方向の街路幅と模型高さのアスペクト比が 4 のケースにおいて, キャニオン内とその上空の空気の交換量が最大になることを示した。 以上のような単純模型による検討は他にも多数行われている 12)が, 実在都市キャニオンを対象とした複雑流れ場の検討例は少ない。

実在都市キャニオンの流れ場を計測した研究は, 例えば以下のも のがある。Offerle et al. 13)は，スウェーデンのヨーテボリ市内にお ける主流方向の街路幅と模型高さのアスペクト比が 2.1 のキャニオ ン内の日射による表面温度の不均一温度分布と流れ場に関する実測 を行った。その結果，計測された乱流熱フラックスの大きさと方位 は, 加熱された壁面に対する風向に強く依存寸ることを明らかにし た。風洞実験では以下の例がある。Klein and Rotach ${ }^{14)}$ は, ナント 市内を対象に実験データを基にしたレイノルズストレスのパラメー 夕化を提案することを目的として, 都市キャニオン内の詳細な流れ 場の計測を行った。その結果, キャニオン内における様々な測定点 の乱流挙動からレイノルズストレスのピーク值の大きさとその高さ を基にしたレイノルズストレスのパラメータ化が提案された。

Robin et al. ${ }^{15)}$ は, Dispersion of Air Pollution and its Penetration into the Local Environment（DAPPLE）16)プロジェクトで, ロン ドン市内を対象に交差点付近から排出された煙の挙動を可視化によ り確認した。上昇流とともに断続的に現れる鉛直方向のせん断層の 渦と交差点内に生成される水平方向の渦によって, 交差点近傍の流 れ場は非常に不規則であることを明らかにした。Carpentieri et al. 17)も, 同じく DAPPLE16)でロンドン市内を対象に, 実在都市キャニ オンにおける交差点付近の流れ場を検討した。その結果, 交差点近 傍では複雑な循環渦が形成され，その構造が污染物質の拡散に強く 影響することを明らかにした。このように，交差点付近の流れの挙 動は明らかになりつつある。しかしながら, 居住空間周辺の
風通しを検討するためには，交差点付近だけでなく，建物に挟まれ たキャニオン内の循環渦の構造および乱流挙動の空間分布を正確に 把握することが重要である。

そこで，本研究では実在都市における様々なキャニオン内の循環 渦の構造および乱流挙動を把握するため, 異なる建物幅やアスペク 卜比の様々なキャニオンを対象に実験を行い, 得られた知見から実 在都市における様々なキャニオン内の循環渦の構造および乱流挙動 と居住空間周辺の風通しの関係を明らかにすることを最終目的とす る。

風洞実験を実在都市の流れ場に適応する場合, 都市の微細な形状 （建物のバルコニー，外階段，壁面などの凹凸，看板，街灯などの 粗度）を陽的に再現することは非常に困難であるため，ある程度の 簡略した都市形状の模型を使わざるを得ない。しかしながら，その ような簡略化した都市形状を適用した風洞実験において, 実在キャ ニオン内の流れの再現精度は明らかでない。

そこで, キャニオン内の循環渦の構造および乱流挙動を把握する 前に, 実測データとの比較による風洞実験の妥当性の検討が必要不 可久である。本報では，萩島らが実測を行った旧桜堤団地(東京都武 蔵野市) 18)を対象に, 簡略化した都市形状模型を適用した風洞実験を 行い，実測值と比較することにより風洞実験結果の再現精度の検討 を行った。

\section{2. 実験概要}

\section{1. 風洞および計測装置}

本風洞実験は，(財) 電力中央研究所・我孫子地区に設置されてい る乱流輸送モデリング風洞（Twinned wind tunnel: TWINNEL）を 用いて行った。本風洞は, 測定部の断面積および長さの異なる二種 類の試験セクション（第 1 試験セクション：長さ $17 \mathrm{~m} \times$ 幅 $3.0 \mathrm{~m} \times$ 高さ $1.7 \mathrm{~m}$ 、第 2 試験セクション: 長さ $10 \mathrm{~m} \times$ 幅 $1.0 \mathrm{~m} \times$ 高さ $1.0 \mathrm{~m})$ を有しており, 可動式のコーナーベーンで切り替えて使用寸る。本 研究では, 第 1 試験セクションにて実験を行った。試験セクション 上流の整流部には八ニカムおよびメッシュが取り付けられており, 試験セクション内に模型等がない場合には, 平均風速の変化, 乱流 強度はともに壁面近傍を除き断面全体で $1 \%$ 以内である。風速測定 には，2 次元レーザドップラー流速計 (LDV: Laser Doppler Velocimeter）と粒子画像流速測定法（PIV：Particle Image Velocimetry）を用いた。

本実験では，DANTEC DYNAMICS 社製の $14 \mathrm{~mm}$ めファイバプ ローブを試験セクション内のトラバース装置に取り付け, LDVによ って主流（流れ）方向とスパン方向，鉛直方向の風速三成分を計測 した。風速測定のためのトレーサ粒子として, 発煙装置を用いて発 生させたオイルフォグを測定部入口付近より風洞内へ添加した。 LDV のサンプリング条件は, データ取得数 10,000 点または測定時 間 60 秒とした。このサンプリング条件に関しては, データ取得数 および測定時間を増加させた場合でも測定結果に変化が無いことを 予め確認している。

LDV による計測に加え, PIVによる計測も行った。本実験では, NEW WAVE RESEARCH 社製の Nd:YAG レーザ（出力 $120 \mathrm{~mJ}$, 波長 $532 \mathrm{~nm}$ ）を用いて天井面よりレーザシート光を照射し, 試験セ クション内に設置した CCD カメラ $(1344 \times 1024 \mathrm{pixel})$ により撮影 
を行った。レーザシート厚は約 $3 \mathrm{~mm}$, カメラレンズは焦点距離 $60 \mathrm{~mm}$ のものを用いた。PIV では, 撮影間隔 $1.2 \mathrm{msec} の 2$ 枚の画 像を 1 秒間に 15 組撮影し, 180 秒間の計測より平均風速 2 成分を 求めた。画像相関法は, 適応相関を用いた。探查空サイズは $32 \times 32$ pixel でオーバーラップ率は $50 \%$ とした。各 pixel の速度べ クトルを算出した後に周囲の速度ベクトルとの比較により誤べクト ルの除去を行った。

\section{2. 建物模型}

流れ場の計測概要を図 1 に示寸。測定座標系は試験セクション入 口の床面中央を原点とし，風洞主流（流れ）方向を $X$, 流れ方向に 対して直交する横断（スパン）方向を $Y$, 鉛直方向に $Z$ とした。な お, 流れ方向およびスパン方向, 鉛直方向の平均風速をそれぞれ $U$, $V, W$, 変動風速 $u^{\prime}, V^{\prime}, W^{\prime}$ の標準偏差をそれぞれ $\sigma_{u}, \sigma_{V}$, $\sigma_{W}$ と記す。本実験では建物模型の縮尺率を実在都市キャニオン $\left.{ }^{17}\right)$ の $1 / 150$ とした。

試験セクション入口から $1.55 \mathrm{~m}$ の風下位置にスパイヤを, そこ から $1.32 \mathrm{~m}$ 離れた風下に高さ $30 \mathrm{~mm}$ の $\mathrm{L}$ 型アングルを $1.32 \mathrm{~m}$ 間 隔で 5 本設置し（図 1）測定範囲において十分に発達した境界層が 形成されるように気流の調整を行った。実験風速 $U_{\text {。は境界層上空 }}$ $(Z=1.0 \mathrm{~m})$ で $3.0 \mathrm{~m} / \mathrm{s}$ と設定した。

風洞実験で用いた模型の写真を図 $2, X=7.2 \mathrm{~m}$ における流入風の 平均風速および風速変動の標準偏差を図 3 に示す。 $Z=1.0 \mathrm{~m}$ での平 均風速 $U_{\infty}$ で無次元化した平均風速 $U / U_{\infty}$ の分布は, 図中の実線で示 す $1 / 5$ べき乗則に従っており，低層住宅地上空の風速分布に相当す る。本実験の境界層高さ $Z_{\infty}$ は $1 \mathrm{~m}$ であり, 実現象では $150 \mathrm{~m}$ となる。 また，粗度長は実スケールで $60 \mathrm{~cm}$ であり，市街地 ${ }^{19)}$ のもに相当 する。風速変動の標準偏差は $\sigma_{u}, \sigma_{v}, \sigma_{w}$ の順に大きく, 地表面近 傍では上空風 $U_{\infty}$ に対して, およそ $10 \%$ 程度の乱れが生成されてい る。

桜堤団地模型の立体概略図を図 $4 \mathrm{a}$, 計測対象キャニオン断面図を 図 $4 \mathrm{~b}$ に示す。対象とした風向はこの地域の卓越風向である北とし た。 $X$ 軸は北から南向き， $Y$ 軸は西から東向きに設定した。図 $4 \mathrm{a}$ の中央部の南北方向に並んだ 4 棟の建物で形成されたキャニオンを 「中央キャニオン」とし, その東側のキャニオンを「東キャニオン」, その西側を「西キャニオン」とした。(以後, それぞれ「中央キャニ オン」,「東キャニオン」,「西キャニオン」と呼ぶ。）中央キャニオン および東キャニオンの屋根はフラットであるが，西キャニオンは傾 斜のついた三角形の屋根である。本報では実測が行われた中央キャ ニオンを対象とした。地上高さを $Z$ ，建物高さを $H$ ，建物幅を $L$, 建物間の幅を $W$ と定義する。なお，図 $4 \mathrm{a}$ で示寸変数の下付の添え 字 $c, W ， e$ はそれぞれ中央キャニオン，西キャニオン，東キャニオ ンの值を示す。ただし，下付の添え字がない $H$ は中央キャニオンの 值である。建物間の幅に基づくアスペクト比は $W_{w} / H_{w}=1.46, W d H$ =1.72, $W_{e} / H_{e}=1.70$ であり, 西キャニオンのアスペクト比が他のキ ヤニオンのものに比べ小さい。また, 建物幅に基づくアスペクト比 は， $L_{w} / H_{w}=5.09, L_{d} H=3.91 ， L_{e} / H_{e}=2.55$ であり西から順に小さく なる。建物の長辺は風向にほぼ直交するが，およそ $5-8^{\circ}$ ずれてい る。中央キャニオン $\mathrm{C} 1$ の主流方向断面（緑線部分）において実測 值との比較を行った。図 $4 \mathrm{~b} の 1 ５$ は主流方向断面（緑線部分）の

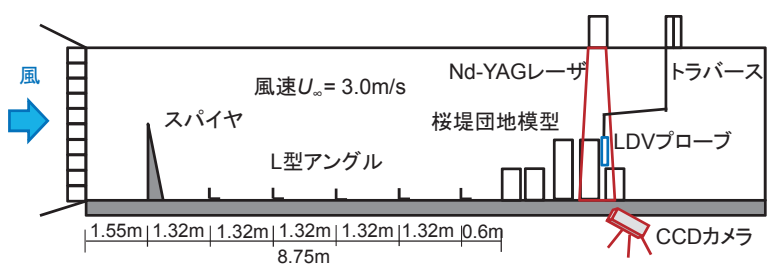

図 1 流孔場の計測概要

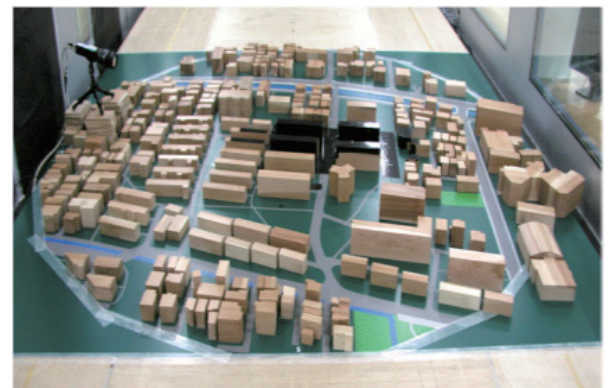

図 2 風洞実験模型

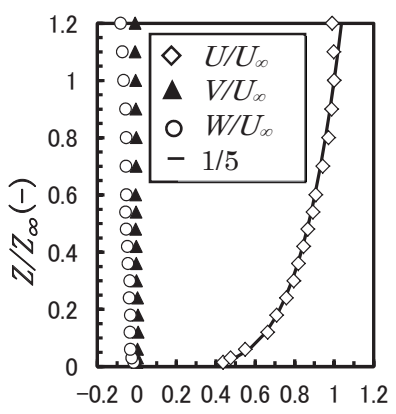

$U / U_{\infty}(-) \quad V / U_{\infty}(-) \quad W / U_{\infty}(-)$ a 平均風速

図 3 平均風速と風速変動の標準偏差 $(X=7.2 \mathrm{~m})$

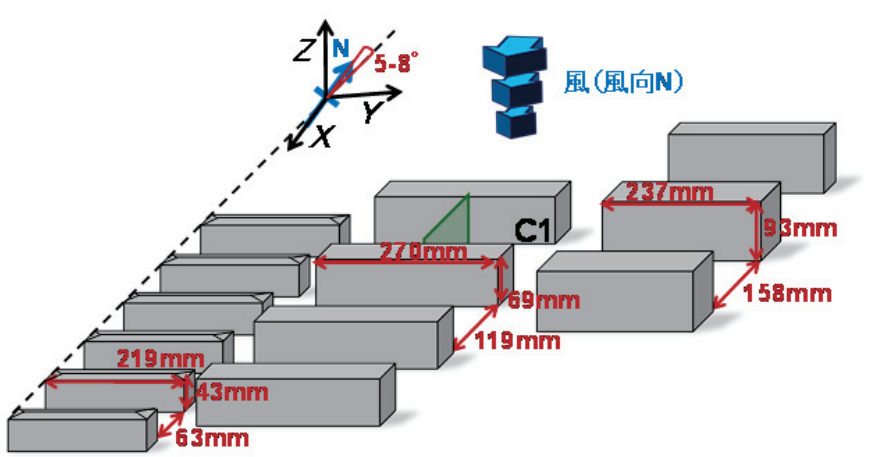

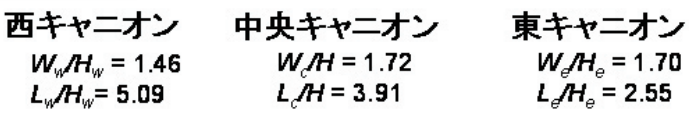

a 桜堤団地模型の立体概略図

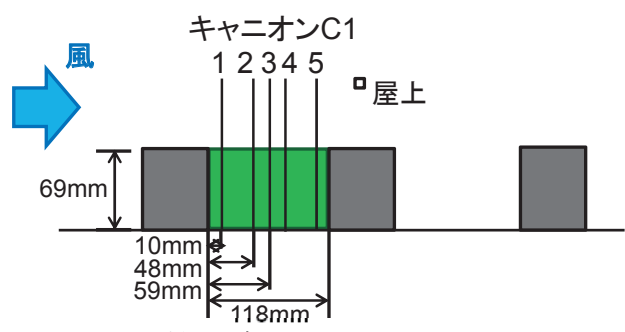

b 計測対象キャニオン断面図

図 4 計測対象領域 
計測点である。

\section{3. 実験結果}

風洞実験によるキャニオン内の流れ場の再現精度を検討するため, PIV と LDV による風洞実験結果を既往の屋外実測值と比較した。 比較に用いた実測值は, 2004 年 9 月 22 日〜 2004 年 12 月 2 日に旧 桜堤団地で行われたものであり, 実測の詳細については萩島らの論 文18)に述べられている。風速の測定に用いられた機器は, 3 次元超 音波風向風速計 ( $5 \mathrm{~cm}$ スパン: KAIJO WA (T) -395+DA-600, $10 \mathrm{~cm}$ スパン: KAIJO SAT-540, SAT-530, Young CYG-81000, EKO USA-1）である。サンプリング周波数・平均化時間は, $10 \mathrm{~Hz} \cdot 10$ 分である。この実測結果より大気安定度がほぼ中立（リチャードソ ン数がー0.09 0.08）で, 風向が本風洞実験条件と最も近い幾つか の時刻のデータ $(2004$ 年 11 月 4 日 $10: 30 \sim 10: 40,12: 00 \sim 12: 10$, $12: 10 \sim 12: 20,11$ 月 5 日 8:20 8:30, 11 月 24 日 10:30 10:40, 11 月 25 日 12:20〜 12:30) を抽出し, その平均值を比較対象とした。 実測值との比較は, 実測值のない $\mathrm{C} 1-3$ を除く $\mathrm{C} 1-1 \sim \mathrm{C} 1-5$ の 4 地 点で行った。(C1-3 は LDV と PIV の比較のみ)

平均風速 $U I U_{1.8 H}$ を図 5 , 平均風速 $W U_{1.8 H}$ を図 6 に示す。図中の 横バーは実測から抽出した各統計量の 6 つの時間帯の 10 分間サン プルをアンサンブル平均する際に用いた時間平均值に対する偏差の 最大值と最小值の範囲を示す。まず, 実測データにおける平均風速 の偏差を考える。 $U$ も $W$ も平均值に対して数\%の差異であり非常 に小さい。特に, Uの偏差は非常に小さく、横バーがプロットに隠 れているケースが多い。これは, ほぼ同様の大気安定度と風向であ れば，キャニオン内には同様な流れが形成されることを意味してい る。風洞実駼結果は $Z H=1.8$ における $\mathrm{C} 1-2 \sim \mathrm{C} 1-5$ の 4 点平均によ る $\mathrm{LDV}$ の平均風速 $U_{1.8 H}$ で無次元化した。なお， $\mathrm{C} 1-1$ では周囲の 模型建物との干渉により LDV のプローブがキャニオン内に入らな かったため, LDVでの測定は行っていない。Brown et al.8)や佐藤 ら20)の単純建物により形成されたキャニオン内流れの風洞実験結 果と同様に,キャニオン下方で主流方向と逆の流れが生じる。また, キャニオン側壁の $\mathrm{C} 1-1$ と 1 -5 の W $W$ 絶対值が大きいことから， 実在都市キャニオン内にも循環流が形成されることがわかる。風下 側建物近傍の C1-5 において, LDV と PIV から得られた $W か ゙$ 実測 值と少し差異がみられるが，それ以外の測定点では風洞実験の平均 風速はキャニオン内（ZIH<1.0）で実測值と良い一致を示す。本実 験では建物のベランダなど微細な構造を考慮しなかったが, 実在団 地で行われた実測值と本実験結果は良好に一致した。

壁面近傍の C1-5 において, 平均風速 $W$ の風洞実験結果と実測值 に多少差が見られる原因として, 建物近傍では風速が遅いため, LDV, PIV のトレーサ粒子であるオイルミストが入りにくいことな どが挙げられる。そのため, C1-5 における LDV, PIVの結果は測 定誤差も一因と考えられる。しかしながら, 実測值にも風向変動等 の外乱の影響が含まれていることを考えると, 両者の差異は非常に 小さいと考えられる。

風速変動 $u^{\prime}$ の標準偏差 $\sigma u l U_{1.8 H}$ を図 7 , 風速变動 $W^{\prime}$ の標準偏 差 $\sigma_{w} / U_{1.8 H}$ を図 8 に示寸。 $Z H=1.8$ の実測值（図中の $\square$ 印）は，キ ヤニオン $\mathrm{C} 1$ の風下建物上空で計測された值であるが，参考のため にすべての地点にプロットした。キャニオンの上空（ZIH>1.0）に
おいて， $\sigma_{u}$ の風洞実験結果は実測值よりおよそ 2 倍程度小さくな る。これは, 実大気中にはメソスケール擾乱などの比較的大きな乱 流渦が存在するが, 風洞実験ではアクティブグリッド（例えば, Michioka et al.$\left.^{21)}\right)$ などの特殊な装置を用いなければそれらの渦を
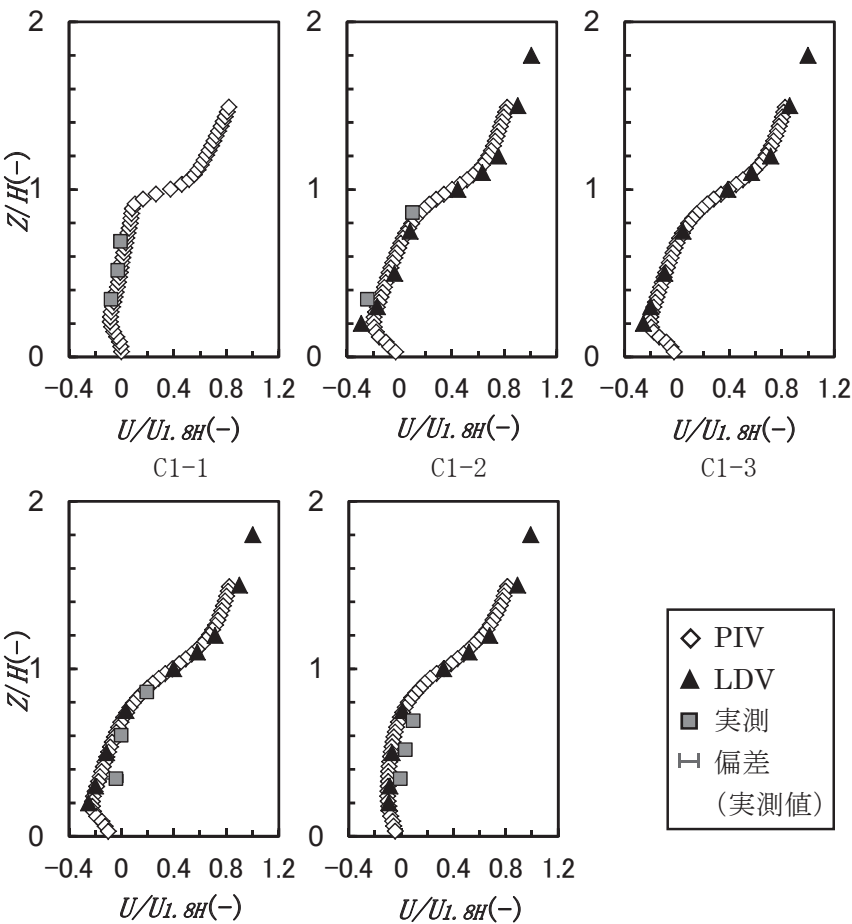

C1-2

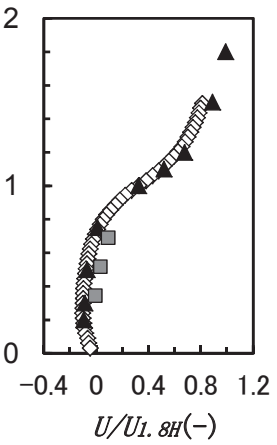

C1-3

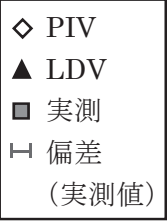

C1-4

C1-5

図 5 平均風速 $U U / U_{1.8 H}$

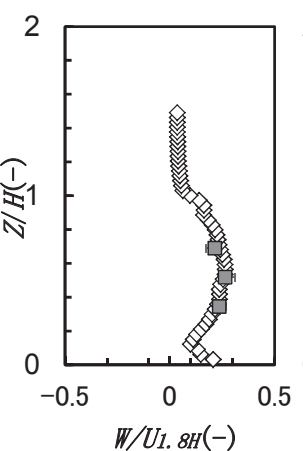

C1-1

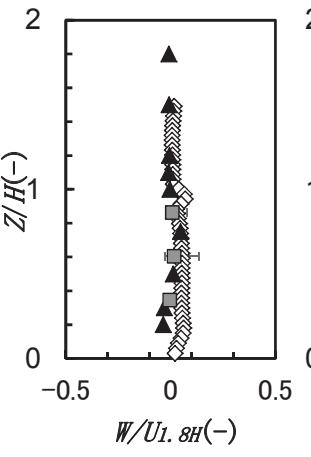

C1-4

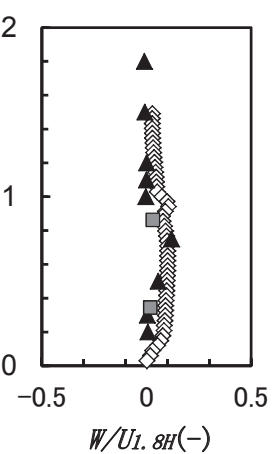

C1-2

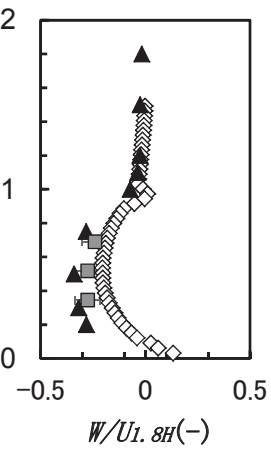

C1-5

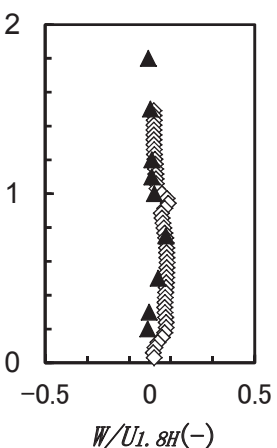

C1-3

\begin{tabular}{|ll}
$\Delta$ & PIV \\
$\Delta$ & LDV \\
$\square$ & 実測 \\
$\mapsto$ & 偏差 \\
& (実測値) \\
\hline
\end{tabular}

図 6 平均風速 $W \quad W / U_{1.8 H}$ 

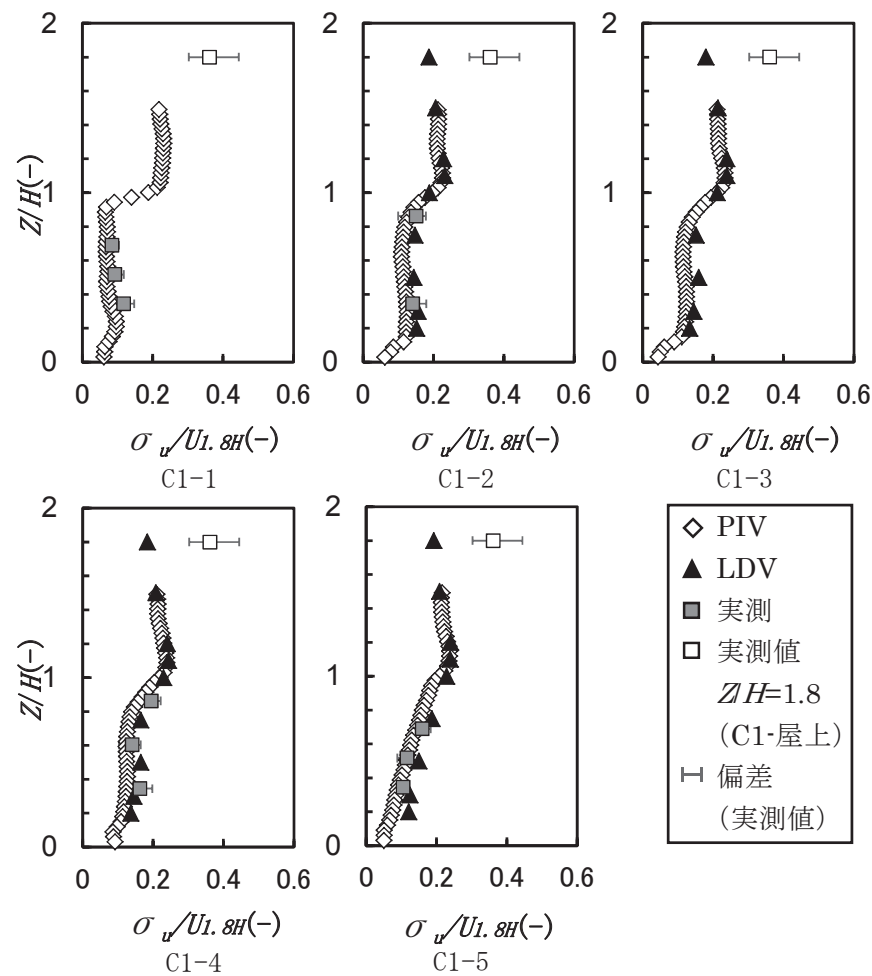

$\mathrm{C} 1-4$

$$
\mathrm{C} 1-5
$$

図 7 風速変動 $u^{\prime}$ の標準偏差 $\sigma_{u} \quad \sigma_{u} / U_{1.8 H}$
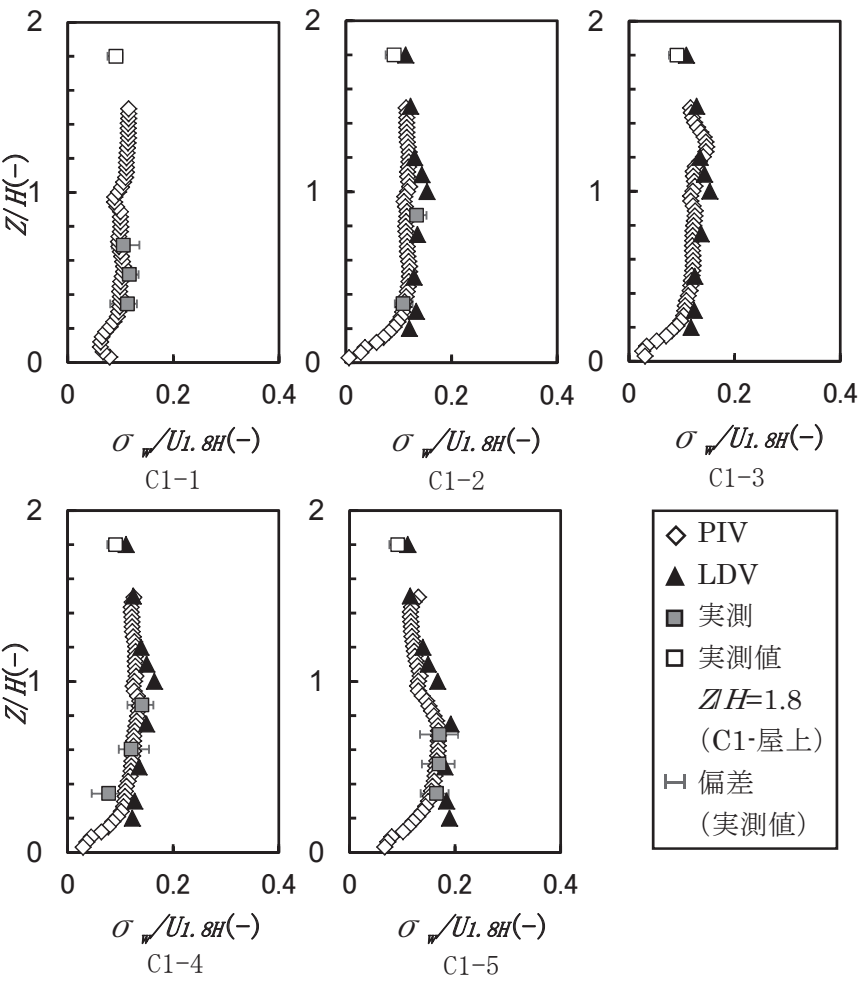

$\mathrm{C} 1-3$

\begin{tabular}{|l|}
\hline$\diamond \mathrm{PIV}$ \\
$\Delta \mathrm{LDV}$ \\
$\square$ 実測 \\
$\square$ 実測值 \\
$\quad Z I H=1.8$ \\
$\quad(\mathrm{C} 1$ - 屋上) \\
$\mapsto-1$ 偏差 \\
$\quad$ (実測值 $)$ \\
\hline
\end{tabular}

図 8 風速変動 $\boldsymbol{w}^{\prime}$ の標準偏差 $\sigma_{w} \quad \sigma_{w} / U_{1.8 H}$

再現できないためである。一方，キャニオン内（ZIH<1.0）におい ては，風洞実験の $\sigma_{u}$ は実測值とほぼ一致しており，キャニオン内 では建物により形成される乱流渦が実大気中の擾乱の影響より支配 的である。これは、キャニオン上空 $(Z / H>1.0)$ において、上空の 実測值 $\sigma_{u}$ の偏差が大きいのに対して, キャニオン内 $(Z I H<1.0)$ の $\sigma_{u}$ の偏差が小さいことからも判断できる。
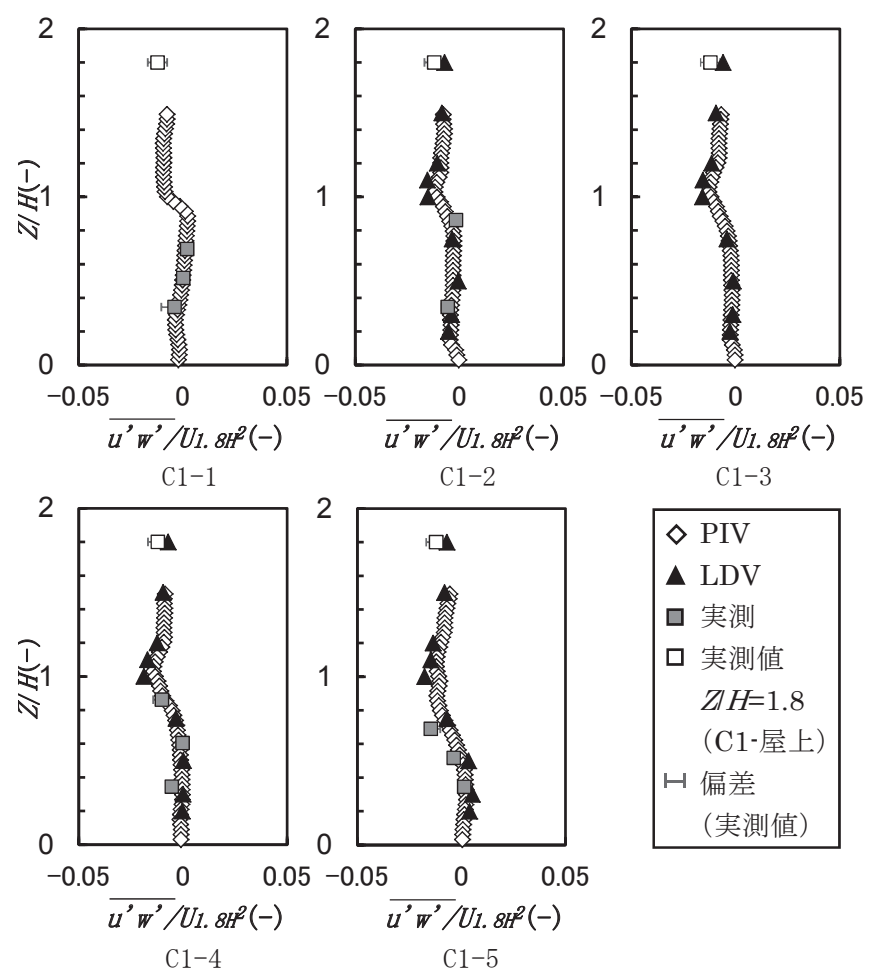

C1-2

C1-3
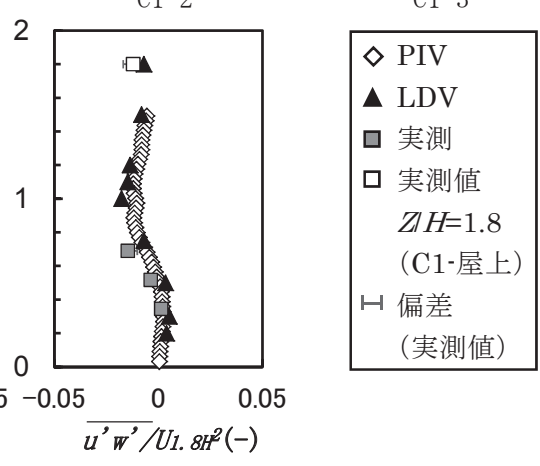

図 9 レイノルズストレス $\overline{u^{\prime} w^{\prime}} \quad \overline{u^{\prime} w^{\prime}} / U_{1.8 H}^{2}$

また，キャニオンの上空（ZIH>1.0）において， $\sigma_{w}$ の風洞実験結 果は実測值とほぼ同様であり高さ方向にほぼ一定である。このキャ ニオン上空における $\sigma_{w}$ は $\sigma_{u}$ とは異なる傾向であるが，屋外都市ス ケールモデルで得られた結果 222123) と一致した。これは， $\sigma u$ は外層 スケールの変動が支配的であるが， $\sigma_{W}$ は地表面条件に依存するた めである 23 。

一方，キャニオン内（ZIH<1.0）においては，風洞実験の $\sigma_{W}$ は実 測值とほぼ一致しており， $\sigma_{u}$ と同様に建物により形成される乱流 渦が実大気中の擾乱の影響より支配的であることがわかる。

$\mathrm{PIV}$ と LDV の $\sigma_{u}, \sigma_{W}$ を比較するとほとんど違いが見られない が, 乱れが強い C1-5 で LDVの $\sigma_{w}$ が PIVより若干大きい。これは, LDV の方が高応答でより小さな乱流変動を計測しているためであ ると考えられる。

乱流運動による運動量輸送を表すレイノルズストレス $\overline{u^{\prime} w^{\prime}} / U_{1.8 H}{ }^{2}$ を図 9 に示す。風洞実験結果は実測值と良く一致しており, 建物高さ近傍の $\overline{u^{\prime} w^{\prime}} / U_{1.8 H}^{2}$ のピーク值も捉えている。これは, レイ ノルズストレスも $\sigma_{W}$ と同様に, 建物により形成された乱れに強く 支配されるためである 22$)$ 。また, 実測值と比べて風洞実験の $\sigma_{u}$ は 小さいが， $\overline{u^{\prime} w^{\prime}} / U_{1.8 H}{ }^{2}$ にほとんど差異は見られない。これは，実大 気中には境界層の上層で形成される比較的大きな洞が存在するため,

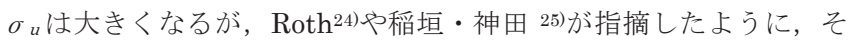
の渦は $\overline{u^{\prime} w^{\prime}} / U_{1.8 H}^{2}$ にほとんど影響を与えないためと考えられる注 1)。 キャニオン内では, $\overline{u^{\prime} w^{\prime}} / U_{1.8 H}^{2}$ はほぼゼロとなり, 乱流運動は運動 量輸送にほとんど寄与していない。風洞実験から得られた上空の $\sigma u$ が実測值より大きくなることや, $\sigma_{W} や \overline{u^{\prime} w^{\prime}}$ が実測值に比較的良い一 致を示寸傾向は, 既往の屋外都市スケールモデルの研究 21)22) と良く 類似している。

以上のように, 実測結果と比較することにより, 実在都市キャニ 
オンを対象とした風洞実験において, 平均流だけでなく乱流統計量 を含めたキャニオン内の流れ場の特性を再現できることが明らかに なった。

\section{4. まとめ}

実在都市キャニオン内における流れ場の再現性を検討するため, 旧桜堤団地(東京都武蔵野市) を対象とした風洞実験を行い PIV (Particle Image Velocimetry) と LDV (Laser Doppler Velocimeter）によってキャニオン内の流れ場を計測した。風洞実験 結果の妥当性を検討するため, 実測結果との比較検討を行い, 以下 の知見を得た。

1.

実測において，上空の風向や大気安定度がほぼ同様の 条件下であれば, キャニオン内には再現性のある流れ場 が形成される。

2. 実在都市キャニオン模型を用いた風洞実験結果を,キ ヤニオン内の多点において実測值と詳細に比較するこ とにより, 実現象に近いキャニオン内の流れ場の特性を 再現できることを明らかにした。本実験では，建物の ベランダなど微細な構造を考慮しなかったが, 平均風速, 乱れ強さは実測值と良く一致した。

3.

キャニオンの上空において, 風洞実験では実大気中の メソスケール擾乱などの比較的大きな乱流渦を再現で きないため, 主流方向の風速変動の標準偏差は 実測值より小さくなる。一方, 鉛直方向の風速変動の標 準偏差とレイノルズストレスは, 建物により形成された 乱れに強く支配されるため, 実測值に近い值となる。こ れらの傾向は, 既往の屋外都市スケールモデルの実測お よび風洞実験による結果と良く一致している。

以上より，風洞実験結果が実現象に近いキャニオン内の流れ場の 特性を再現できることが明らかになった。次報では風洞実験による 実在都市キャニオン内の循環渦の構造および乱流挙動の解明を行う。

\section{謝辞}

本研究の遂行に際し, 日本工業大学 成田健一教授, 防衛大学校 菅原広史准教授, 九州大学 谷本潤教授らによる現地実測データを 使用させて頂いた。また, 九州大学 谷本潤教授, 東京工業大学 神 田学教授には風洞実験に関して貴重なご意見をいただいた。ここに 記して謝意を表します。

\section{参考文献}

1）経済産業省資源エネルギー庁: 平成 21 年度エネルギーに関する年次報告 (エネルギー白書 2010)，2010.6.

2) 成田健一: 風の道と都市気候形成, 日本風工学会誌, 第 107 号, pp. 109-114, 2006. 4 .

3）例えば河野良坪, 加藤信介, 大岡龍三, 高橋岳生 : 横風時における単一 開口換気の特性に関する実験的研究 片壁面上の夕に開口を有する居室の 換気性状に関する研究 (その 1), 日本建築学会環境系論文集, 第 611 号, pp. 29-35, 2007. 1 .

4) 久保田徹, 三浦昌生, 富永禎秀, 持田灯: 実在する $270 \mathrm{~m}$ 平方の住宅地に
おける地域的な風通しに関する風洞実験 建物群の配置・集合形態が地域 的な風通しに及ぼす影響 (その1), 日本建築学会計画系論文集, 第 529 号, pp. 109-116, 2000.3.

5）久保田徹, 三浦昌生, 富永禎秀, 持田灯：風通しを考慮した住宅地計画 のための全国主要都市におけるグロス建ぺい率の基準值＼cjkstart建築群の配置・ 集合形態が地域的な風通しに及ぼす影響（その 2），日本建築学会計画系 論文集，第 556 号，pp. 107-114，2002.6.

6）義江 龍一郎, 田中 英之, 白澤 多一, 小林 剛：高層密集市街地におけ る建物群の形態が歩行者レベルの風速・気温分布に与える影響, 日本建築 学会環境系論文集, 第 627 号, pp. 661-667, 2008.5.

7) M.J. Brown, R.E. Lawson, D.S. Decroix and R.L. Lee: Mean Flow and Turbulence Measurement around a 2-D Array of Buildings in a Wind Tunnel, Report LA-UR-99-5395, Los Alamos National Laboratory, Los Alamos, 7pp, 2000.1.

8) M.J. Brown, R.E. Lawson, D.S. Decroix and R.L. Lee: Comparison of Centerline Velocity Measurements Obtained Around 2D and 3D Building Arrays in a Wind Tunnel, Proceedings of the 2001 International Symposium on Environmental Hydraulic, 2001.12.

9) B. Leitl, K. Bezpalcova, F. Harms: Wind Tunnel Modelling of the MUST Experiments, Proceeding of the $11^{\text {th }}$ International Conference on Harmonization within Atmospheric Dispersion Modelling for Regular Purposes, pp.435-439, 2007.7.

10) E. Yee and C.A. Biltoft: Concentration Fluctuation Measurements in a Plume Dispersing through a Regular Array of Obstacles, Boundary Layer Meteorology, Vol.111, pp.363-415, 2004.11.

11) B. Monnier, B. Neiswander and C. Wark: Stereoscopic Particle Image Velocimetry Measurements in an Urban -Type Boundary Layer: Insight into Flow Regimes and Incidence Angle Effect, Boundary Layer Meteorology, Vol.135, pp.243-268, 2010.2.

12) M. Kanda: Progress in the scale modeling of urban climate Review, Theor. Appl. Climatol., Vol.84, pp.23-33, 2005.9.

13) B. Offerle, I. Eliasson, C.S.B. Grimmond and B. Holmer: Surface Heating in Relation to Air Temperature, Wind and Turbulence in an Urban Street Canyon, Boundary Layer Meteorology, Vol.122, pp.273-292, 2006.8 .

14) P.K. Klein and M. Rotach: Mean Flow and Turbulence Characteristics in an Urban Roughness Sublayer, Boundary Layer Meteorology, Vol.111, pp.55-84, 2004 .

15) A. Robins, H. Cheng, P. Hayden and T. Lawton: Flow Visualisation Studies - I, Note DAPPLE - EnFlo 04, 2004.5.

16) S.J. Arnold, H. ApSimon and J. Barlow et al.: Introduction to the DAPPLE Air Pollution Project, Science of the Total Environment, Vol.332, pp.139-153, 2004.10.

17) M. Carpentieri, A.G. Robins and S. Baldi: Three-Dimensional Mapping of Air Flow at an Urban Canyon Intersection, Boundary Layer Meteorology, Vol.133, pp.277-296, 2009.9.

18）萩島理, 成田健一, 菅原広史, 谷本潤 : 実大スケール都市キャノピーの 表面対流熱伝達率分布に関する観測, 日本建築学会環境系論文集, 第 626 号, pp. 511-518, 2008. 4 .

19）社団法人日本鋼構造協会編：構造物の耐風工学, 東京電機大学出版局, 
1997.

20）佐藤歩, 道岡武信, 田中伸幸, 市川陽一, 竹内信次, 江守吉洋 : 集合住 宅周辺の気流・熱拡散に関する風洞実験, 電力中央研究所報告 第 08055 号, 2009.7.

21) T. Michioka, A. Sato and K. Sada: Wind tunnel experiments for gas dispersion in an atmospheric boundary layer with large scale turbulent motion, Boundary Layer Meteorology, Vol.141, pp.35-51, 2011.7.

22）佐藤歩, 瀧本浩史, 道岡武信, 神田学: 建物キャニオン内の流れと拡散 に関する屋外都市スケールモデル実験, 土木学会水工学論文集, 第 53 号, pp. 247-252, 2009. 2.

23) A. Inagaki and M. Kanda: Turbulent Flow Similarity over an Array of Cubes in Near-neutrally Stratified Atmospheric Flow, Boundary Layer Meteorology, Vol.615, pp.101-120, 2008.

24) M. Roth: Review of atmospheric turbulence over cities, Q.J.R. Meteorolol. Soc., 126, pp.941-990, 2000.4.

25）稲垣厚至, 神田学: 屋外都市スケールモデルで観測された乱流統計量の 鉛直分布, 土木学会水工学論文集, 第 51 号, pp.247-252, 2007.2.

注

注 1) 上空の乱れには境界層の上層で生成される inactive turbulence と地表 面近傍で生成される active turbulence の 2 種類があり, 既往の文献から inactive turbulence は運動量輸送に寄与しないことが確認されている。そ のため, active turbulence を適切に再現できれば，実測のレイノルズスト レスを風洞実験で再現可能だと考えられる。

また, Michioka et al.は active grid と呼ばれる特殊な装置を用いて境界 層の上部の乱れを増加させた風洞実験で，。uは大きくなるがレイノルズス トレスは変化がないという結果を示した。

さらに，本実験の異なる境界層高さによる実験結果の比較例を以下に示 す。境界層高さを変化させると $\sigma \mathrm{u}$ は変化しても，レイノルズストレスはほ とんど変化しない結果となった。この結果からもレイノルズストレスは地 表面から生成される active turbulence に支配されるという結果を支持し ている。
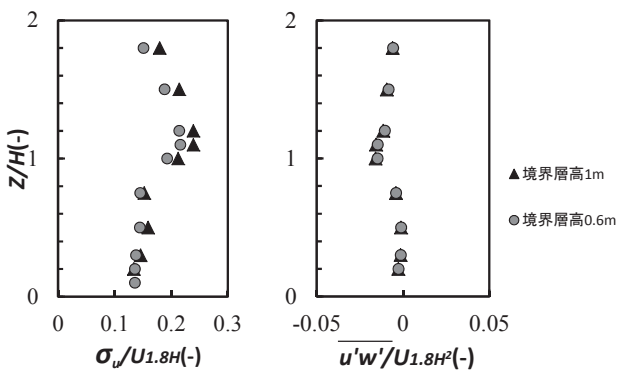

異なる境界層高さによる実験結果の比較例

（2011年 7 月28日原稿受理，2011年12月19日採用決定） 